\title{
DOUBTING ABRAHAM DOUBTING GOD: THE CALL OF ABRAHAM IN THE OR HA-SEKHEL
}

\author{
Benjamin Williams*
}

\begin{abstract}
Abraham ben Asher's Or ha-Sekhel, an exposition of Genesis Rabba, was published in Venice in 1567. The author frequently interprets midrashim by listing and then harmonising series of "doubts" or "questions" (sefekot or she elot) that arise in the text. The present study analyses this mode of exegesis by examining Abraham ben Asher's interpretation of the exposition of the Call of Abraham at Genesis Rabba 39:1. The midrash likens the biblical account (Genesis 12:1) to a wayfarer who, on seeing a burning building, asked whether anyone was in charge and was subsequently confronted by the owner. Thus Abraham asked whether anyone was in charge of the world and then received his divine mandate. Abraham ben Asher begins his interpretation with a startling observation: the midrash seems to imply that Abraham questioned the existence of God. In the harmonising interpretation that follows, Abraham ben Asher reassures the reader that the patriarch considered the nature of divine providence rather than God's existence. Nevertheless, as this paper argues, he deliberately led his audience to entertain the notion that Abraham once lacked a proper understanding of monotheism. This serves a rhetorical purpose, capturing the reader's interest in how the expositor will solve the problem he raised. By assailing readers with questions and then providing solutions, Abraham ben Asher also creates the impression that any uncertainties that may arise in the study of midrash will inevitably have satisfactory resolutions because the sages' words can always be expounded so as to reveal harmonious and coherent interpretations.
\end{abstract}

The early modern Sephardi communities of the Ottoman Empire were hothouses of midrashic creativity. The fundamental importance of Rashi's commentaries in the educational curriculum and for the study of the weekly Torah reading ensured that those literate in Hebrew cut their teeth on the copious midrashim he cites. ${ }^{1}$ Midrash also featured in the weekly sermons delivered by communal rabbis, who customarily expounded the appointed Torah portion in the light of a carefully chosen passage of

\footnotetext{
" Leverhulme Early Career Fellow, Department of Theology \& Religious Studies, King's College London. Email: benjamin.williams@kcl.ac.uk

1 Yaron Ben-Naeh, Jews in the Realm of the Sultans: Ottoman Jewish Society in the Seventeenth Century (Tübingen: Mohr Siebeck, 2008), 254; Minna Rozen, The Jewish Community of Jerusalem in the Seventeenth Century [in Hebrew] (Tel Aviv: Tel Aviv University and the Ministry of Defense, 1984), 197-201; Michael Molho, "The Talmud Torah School" [in Hebrew], in Salonique: Ville-Mère en Israël (Jerusalem and Tel Aviv: Centre de recherches sur le Judaïsme de Salonique, 1967), 60; David Benvenisti, Yehudei Saloniki ba-Dorot ha-Aharonim (Jerusalem: Kiryat Sefer, 1973), 78; Joseph Karo, Shulhan Arukh, Orah Hayyim, Shabbat, 285:2, ed. Zvi Preisler and Shemuel Havlin (Jerusalem: Ketuvim, 1993), 81; Eric Lawee, "The Reception of Rashi's Commentary on the Torah in Spain: The Case of Adam's Mating with the Animals," JQR 97 (2007): 33-66; Abraham Gross, "Spanish Jewry and Rashi's Commentary on the Pentateuch" [in Hebrew], in Rashi Studies, ed. Zvi Steinfeld (Ramat-Gan: Bar Ilan University Press, 1993), 27-55. In his colophon to the Constantinople 1505 edition of the Pentateuch, Haftarot and Five Scrolls, the editor and proof-reader Joseph ben Ya ish lamented the books no longer available to Jews exiled from Spain and Portugal in the Ottoman Empire: "even should they possess the Pentateuch, they would not have the Targum, and if they had a Targum they would not have [Rashi's] Commentary." The new book, in which the Pentateuch was accompanied by Targum Onkelos and Rashi, supplied these indispensable texts. See Abraham Yaari, Hebrew Printing at Constantinople: Its History and Bibliography [in Hebrew] (Jerusalem: Magnes Press, 1967), 59-60; Nigel Allan, "A Typographical Odyssey: The 1505 Constantinople Pentateuch," in Journal of the Royal Asiatic Society, Third Series, 1 (1991): 343-52.
} 
aggadah. ${ }^{2}$ Books of midrash were printed for the very first time at the Hebrew presses of the Ottoman Empire, and scholars in Constantinople, Salonica and Safed composed and published commentaries to help readers understand them. ${ }^{3}$

The purpose of this paper is to examine an important method of studying and interpreting midrash in the sixteenth century Ottoman Empire as it is exemplified in the commentary on Genesis Rabba by Abraham ben Asher. A pupil of Joseph Karo, Abraham ben Asher was active as a scholar and communal rabbi in the post-expulsion Sephardi communities of Safed, Aleppo and Damascus. He conceived of his magnum opus, the Or haSekhel ("the Light of the Intellect"), as a series of volumes containing the complete Midrash Rabba along with his extensive commentary. Only the first book, subtitled Ma adenei Melekh ("the Delights of the King"), was ever printed. It contains the text of Genesis Rabba together with the medieval commentary mistakenly attributed to Rashi and Abraham ben Asher's own interpretations. The author's relative Judah Falcon brought the work to press in Venice in 1567. It was skilfully typeset in the "talmudic" format at the printing house of Giovanni Griffio, the midrashic text being surrounded by the two commentaries. Abraham ben Asher thereby provided his readers with a self-contained means of studying Genesis Rabba and a comprehensive guide to its interpretation. ${ }^{4}$

Abraham ben Asher frequently employed a popular homiletic mode of exposition, the resolution of specified "questions" (she'elot) and "doubts" (sefekot). This exegetical technique was common in sixteenth-century Sephardi sermons and biblical commentaries, though Abraham ben Asher is the first known to have used it in a commentary on a midrash. ${ }^{5}$ These discourses begin with a barrage of questions in which the author applies the most stringent standards of linguistic consistency and thematic integrity to the text under discussion. This leads the reader to doubt whether it really makes sense. The tensions thus generated are heightened considerably when God or the patriarchs play a

\footnotetext{
${ }^{2}$ See Joseph Hacker, "The Intellectual Activity of the Jews of the Ottoman Empire During the Sixteenth and Seventeenth Centuries," in Jewish Thought in the Seventeenth Century, ed. Isadore Twersky and Bernard Septimus (Cambridge, Mass.: Harvard University Press, 1987), 110-16; Marc Saperstein, Jewish Preaching, 1200-1800: An Anthology (New Haven: Yale University Press, 1989), 22, 74-75; Carmi Horovitz, "Darshanim, Derashot and Derashah Literature in Medieval Spain," in Moreshet Sepharad: The Sephardi Legacy, ed. Haim Beinart (Jerusalem: Magnes Press, 1992), 1:383-98; Mordechai Pachter, "Homiletic and Ethical Literature of Safed in the Sixteenth Century" [in Hebrew] (PhD diss., Hebrew University of Jerusalem, 1976).

s Marc Bregman, "Midrash Rabba and the Medieval Collector Mentality," in The Anthology in Jewish Literature, ed. David Stern (Oxford: OUP, 2004), 196-208; Benjamin Williams, "The Ingathering of Midrash Rabba: A Moment of Creativity and Innovation," in Midrash Unbound: Transformations and Innovations, ed. Michael Fishbane and Joanna Weinberg (Oxford: Littman, 2013), 347-70; Myron Lerner, "The Editio Princeps of Midrash Hamesh Megillot: Studies in the Activities of Hebrew Printers in Constantinople and Pesaro" [in Hebrew], in The A.M. Habermann Memorial Volume, ed. Zvi Malachi (Lod: Habermann Institute for Literary Research, 1983), 289-311; Myron Lerner, "The Works of Aggadic Midrash and the Esther Midrashim," in The Literature of the Sages, ed. Shmuel Safrai et al. (Assen: Royal Van Gorcum and Fortress Press, 2006), 2:167-68.

${ }_{4}$ The biography of Abraham ben Asher and the publication of the Or ha-Sekhel are discussed in detail in the author's Commentary on Midrash in the Sixteenth Century: The Or ha-Sekhel of Abraham ben Asher (Oxford: OUP, forthcoming). See also Williams, "The Ingathering," 359-69; Judah Theodor, "The Commentary on Genesis Rabba" [in Hebrew], in Festschrift zu Israel Lewy's siebzigstem Geburtstag, ed. Marcus Brann and Ismar Elbogen (Breslau: Marcus, 1911), 132-54 (Hebrew section).

${ }^{5}$ Samuel Yafeh of Constantinople also employed the technique in his commentaries on Midrash Rabba entitled Yefeh To'ar (volume 1, on Genesis Rabba, was published in Venice at the press of Giovanni di Gara in 1597). Kalman Bland, "Issues in Sixteenth-Century Jewish Exegesis," in The Bible in the Sixteenth Century, ed. David Steinmetz (Durham, N.C.: Duke University Press, 1990), 50-67; Marc Saperstein, "The Method of Doubts," in With Reverence for the Word, ed. Jane McAuliffe, Barry Walfish, and Joseph Goering (Oxford: OUP, 2010), 139-43, 146; Eric Lawee, "Isaac Abarbanel: From Medieval to Renaissance Jewish Biblical Scholarship," in Hebrew Bible/Old Testament, vol. 2, From the Renaissance to the Enlightenment, ed. Magne Sæbø (Göttingen: Vandenhoeck \& Ruprecht, 2008), 195-6, 198; Joseph Hacker, "The Sephardi Sermon in the Sixteenth Century - Between Literature and Historical Source" [in Hebrew], Pe'amim 26 (1986): 120-24.
} 
role in the midrash and the reader begins to doubt the propriety of their motives, actions or thoughts. But, with consummate exegetical and rhetorical skill, Abraham ben Asher inevitably dispels these doubts in the ensuing discourse where he solves each of the problems he raised. ${ }^{6}$

To illustrate the full potential of this technique to engage the reader's interest in problem-solving exegetical quests, we will turn to a comment in which Abraham ben Asher questions the thoughts and motives of the patriarch Abraham himself. This is his discussion of the famous midrash on the Call of Abraham at the outset of Parashat Lekh Lekha in Genesis Rabba (39:1). The midrash is a petiha (proem) on Genesis 12:1, in which God commands Abraham to leave Ur of the Chaldeans: "Go from your land and your kindred and your father's house to the land that I will show you." ${ }^{7}$ By means of gezerah shavah (exposition based upon lexical analogy), this verse is associated with Psalm 45:1112 , where a royal bride is likewise urged to forsake her "father's house" at the desire of the King. ${ }^{8}$ The centrepiece of the midrash is a parable (mashal) in which Rabbi Isaac likens Abraham to a wayfarer who sees a burning building, wonders who is in charge of it, and is then confronted by the owner. ${ }^{9}$ We will first focus on the mashal itself and then turn to Abraham ben Asher's interpretation.

The midrash reads:

"And the LORD said to Abram, 'Go from your land [and your kindred and your father's house (beit avikha) ...]"'10

Rabbi Isaac opened his discourse: "Hear, O daughter, and see, incline your ear; forget your people and your father's house (beit avikh)." 11

Rabbi Isaac said: It is like a wayfarer who saw a building on fire (birah doleket). He said, "Might you say that this building has no one in charge (manhig)?"12 The owner (ba 'al) of the building looked out (hetsits) at him and said to him, "I am the owner (ba 'al) of the building."

Thus, since Abraham our father was saying, "Might you say that this world has no one in charge (manhig)?" the Holy One, blessed be he, looked out at him and said to him, "I am the owner (ba 'al) of the world."

"The King will desire your beauty for he is your Lord."13

"The King will desire your beauty" - to make you beautiful in the world.

"So bow down to him."14 Thus, "And the LORD said to Abram."15

\footnotetext{
${ }^{6}$ Cf. Bland, "Issues," 55-56.

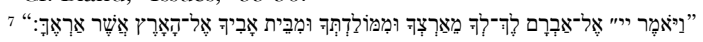

8 "Hear, O daughter, and see, incline your ear; forget your people and your father's house so that the King may

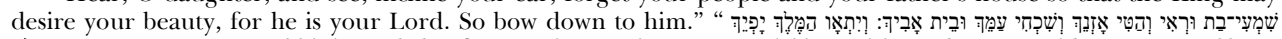

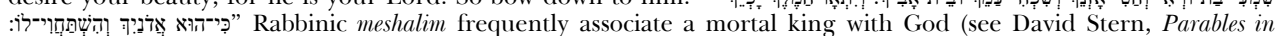
Midrash: Narrative and Exegesis in Rabbinic Literature (Cambridge, Mass.: Harvard University Press, 1991), 19-21). The king of Psalm 45:12, who is designated "your Lord (adonayikh)," is understood in this way here. Cf. the exposition of Song. 3:9 at Pesikta de-Rav Kahana 1:2.

${ }^{9}$ On the role of the mashal within the petiha, see Paul Mandel, "The Call of Abraham: A Midrash Revisited," Prooftexts 14 (1994): 277-78, and cf. Tanhuma (Buber) Lekh Lekha 3.

${ }^{10}$ Gen. 12:1.

${ }_{11}$ Ps. 45:11.

${ }^{12}$ Perhaps a "steward" or "agent" working on behalf of the owner; see Mandel, "The Call," 276.

${ }^{13}$ Ps. 45:12.

14 Ps. 45:12.

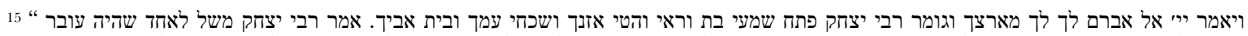

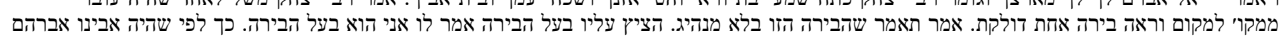


As Paul Mandel has explained, this mashal has long been understood in the light of Maimonides' famous account of Abraham's deduction of the existence of a Prime Cause from the motion of the spheres. At the beginning of Hilkhot 'Avodah Zarah in the Mishneh Torah, Maimonides traced the origins of idolatry to the generation of Enosh who worshipped stars and spheres under the mistaken belief that God desired humans to venerate the bodies he had placed on high. From this fundamental misapprehension developed the more egregious error of worshipping images of the stars and spheres. The degenerating knowledge and worship of God was only halted by Abraham. Maimonides reformulated a range of aggadic texts, perhaps including the midrash under discussion, ${ }^{16}$ to depict him as a pioneer of monotheism who inferred the necessary existence of one God by a process of rational deduction. He described Abraham's discovery as follows:

When [Abraham] was weaned, he began to explore in his mind while he was still small, and he thought day and night, and he wondered, "How is it possible that this sphere could move like this without someone in charge and someone to rotate it, since it could not rotate itself." ... Thus he pondered in his mind until he attained the way of truth and understood the correct line of thought. He knew that there was one God who guides the celestial sphere and created everything, and among all that exists there is no God besides him. ${ }^{17}$

If understood in the light of Maimonides' narrative, the mashal of the wayfarer is a parable of Abraham's discovery of monotheism by means of a teleological argument. On seeing a building, the wayfarer inferred that someone must be responsible for its existence. This conclusion was confirmed when the owner appeared in person. Thus Abraham observed the ordering, direction and purpose of natural bodies and posited the existence of a Prime Cause, an inference confirmed when he received the divine mandate to leave Ur of the Chaldeans. ${ }^{18}$

The Maimonidean understanding of the mashal was certainly known to Abraham ben Asher, who cites and evaluates it in his comment on this midrash. But Abraham ben Asher is also concerned by questions not addressed by this interpretation. Why exactly was the building on fire? Why did the wayfarer's enquiry about someone in charge, an agent or a

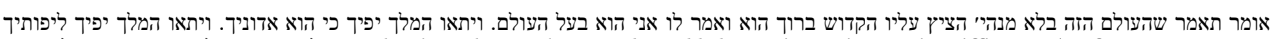
”בעולם והשתחוי לו הוי ויאמר יי' אל אברם. Abraham ben Asher, Or ha-Sekhel (Venice: Giovanni Griffio, 1567), f.81a.

${ }_{16}$ See Mandel, "The Call," 272, 281 n.26; Herbert Davidson, "The Study of Philosophy as a Religious Obligation," in Maimonides the Rationalist (Oxford: Littman, 2011 ), 7.

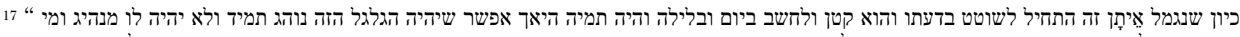

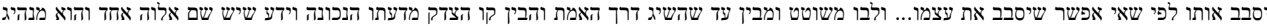
״גלגל והוא ברא הכל ואין בכל הנמצא אלוה חוץ ממנוה. Mishneh Torah, ed. Moses Hyamson (New York: Feldheim, 1981), 1:66b.

${ }^{18}$ According to Mandel, when considered apart from Maimonides, it becomes clear that the wayfarer perceived the burning building and concluded that there really was no manager or agent to care for it and to organise efforts to extinguish the blaze. The owner himself then appeared in the midst of the flames, calling for help. The midrash provocatively and daringly implies that Abraham's consideration of the world led him (initially) to doubt the existence of God. When God addressed him "Go from your land ...," it was the cry of a God who was himself endangered. Mandel shows that the commentary of Jacob Moses Helin (ca. 1625-1700), the Yedei Mosheh, suggests that Abraham thought no one was in charge of the world. Similarly, according to Zeev Wolf Einhorn (the Maharzu, d. 1862), Abraham wondered whether God had taken leave of the world (Mandel, "The Call," 272-73, 277; Midrash Rabbah (Vilna: Romm, 1878), 1:157). To these may be added the interpretation of Elimelech Shapiro of Grodzisk (d. 1892), that Abraham perceived the troubles of the world and the exile of the Shekhinah and supposed that the world must lack a governor (Elimelech Shapiro, Divrei Elimelekh (Warsaw: Halter, 1890), 60). I am grateful to Dr Zvi Stampfer for drawing this to my attention. 
manager, elicit a response from the owner? Answering these questions leads Abraham ben Asher to formulate an innovative interpretation that God commanded Abraham to extinguish the 'fire of idolatry' in the world.

Abraham ben Asher begins by assailing the reader with no less than thirteen doubts and questions. ${ }^{19}$ We will consider his discussion of just one. A problem that particularly vexed him was how the patriarch could have asked, "Might you say that this world has no one in charge?" Could Abraham really have questioned the existence of God? The problem is not whether Abraham was an idolater before he discovered monotheism. ${ }^{20}$ It is that, at the crucial moment when he received the divine mandate to leave his homeland, Abraham seemed strangely unaware that God had been revealed to him on a previous occasion. Abraham ben Asher asks:

Since [Abraham] had been saved from the fiery furnace, what further sign or wonder did he need that the earth had someone in charge? How could he say, "Might you say that this world has no one in charge?"21

Abraham ben Asher here refers to the narrative that Abraham was punished by the Chaldeans for his opposition to idolatry and thrown alive into a fiery furnace. This extrabiblical account, which pre-dates the rabbinic period, is associated with Abraham's departure from Ur of the Chaldeans in Genesis Rabba because the word Ur can mean "flame" or "fire." 22 The fire of the Chaldeans thus refers to their furnace. That the Chaldeans possessed such a facility is well-known from the third chapter of Daniel, where their king Nebuchadnezzar seeks to incinerate Shadrach, Meshach and Abednego. As recounted in Genesis Rabba 44:13, the rescue of Abraham from the furnace was even more remarkable than that of Daniel's companions. While they were only rescued by the archangel Michael, it was God himself who saved Abraham.

\footnotetext{
${ }^{19}$ He refers to them here (as often) as dikdukim and kushyot.

${ }^{20}$ See Geza Vermes, Scripture and Tradition in Judaism, 2nd ed. (Leiden: Brill, 1961), 79-83; cf. Josh. 2:24.

"כיון שנצול מכבשן האש מה היה צריך עוד לאות ולמופת שהעולם יש לו מנהיג ואיך היה אומר תאמ' שהעולם הזה בלא מנהיג" Abraham ben Asher, Or ha-Sekhel, f.81b.

22 Cf. Is. 50:11. Mandel traces aspects of the story in Jubilees 12, Philo's On Abraham, Josephus' Antiquities and The Apocalypse of Abraham (Mandel, "The Call," 268-71). The rabbinic sources that transmit this narrative include Genesis Rabba 34:9, 38:13, 39:3, 44:13; Tanḥuma (Buber) Lekh Lekha 2, 13, 22, Tetsaveh 8; Tanḥuma (printed) Lekh Lekha 2, 6, 10, 18, Va-Yera 3, Toledot 4; Tetsaveh 12; b.Pes. 118a, b.A. Zar. 3a, b.Erub. 53a. Gen. 15:7, "I am the LoRD who brought you out from Ur of the Chaldeans ..." is rendered in Targum Neofiti as "I am the LORD who brought you out from the furnace of fire of the Chaldeans (מן אתון נורהון דכשדאי)." Targum Pseudo-Jonathan provides a detailed narrative of Abraham and Haran in the furnace in its rendering of Genesis 11:28 (Alejandro Díez Macho, ed., Targum Palaestinense in Pentateuchum: Additur Targum Pseudojonatan ejusque Hispanica Versio (Madrid: Consejo Superior de Investigaciones Científicas, 1977-88), 1:71). See Vermes, Scripture, 85-90; Louis Ginzberg, The Legends of the Jews, 2nd ed. (Philadelphia: Jewish Publication Society, 2003), 1:177 n.33; Joanna Weinberg, "Abraham, Exile, and Midrashic Tradition," in Abraham, the Nations, and the Hagarites: Jewish, Christian, and Islamic Perspectives on Kinship with Abraham, ed. Martin Goodman et al. (Leiden: Brill, 2010), 228-29; Robert Hayward, "Inconsistencies and Contradictions in Targum Pseudo-Jonathan: The Case of Eliezer and Nimrod," in Targums and the Transmission of Scripture into Judaism and Christianity (Leiden: Brill, 2009), 227; Carol Bakhos, The Family of Abraham: Jewish, Christian, and Muslim Interpretations (Cambridge, Mass.: Harvard University Press, 2014), 91-96; Menahem Kister, "Observations on Aspects of Exegesis, Tradition, and Theology in Midrash, Pseudepigrapha, and other Jewish Writings," in Tracing the Threads: Studies in the Vitality of Jewish Pseudepigrapha, ed. John Reeves (Atlanta: Scholars Press, 1994), 6-7; James Kugel, Traditions of the Bible (Cambridge, Mass.: Harvard University Press, 1998), 252-54, 267-70. See also Sebastian Brock, "Abraham and the Ravens: A Syriac Counterpart to Jubilees 11-12 and its Implications," JSJ 9 (1978): 135-52; William Adler, "Abraham and the Burning of the Temple of Idols: Jubilees' Traditions in Christian Chronography," JQR 77 (1987): 95-117; Joseph Gutmann, "Abraham in the Fire of the Chaldeans: A Jewish Legend in Jewish, Christian and Islamic Art,” Frühmittelalterliche Studien 7 (1973): 242-52.
} 
Abraham ben Asher mentions this narrative because it raises an acute problem for the interpretation of the midrash under discussion, undermining the unique significance of Abraham's apprehension of God in Genesis 12:1. If Abraham had already been miraculously saved from the furnace of the Chaldeans by divine fiat, why does the mashal now portray him as asking the most basic question about God: "Might you say that this world has no one in charge?" The patriarch's certainty on this important point appears to have been shaken. When this midrash is considered in the light of the earlier narrative of the fiery furnace, therefore, Abraham emerges not as a pioneer philosopher of religion who deduced the existence of God from first principles. Instead he becomes a doubter who was once saved by divine intervention, but now questions the very existence and nature of God.

Abraham ben Asher only raises this question because he wishes to answer it. And a question with such startling implications only heightens the reader's interest in how he will do so. He first considers whether the mashal really describes Abraham's discovery of a Prime Cause, a discussion that hinges on the exact meaning of birah doleket. Did the wayfarer see a building that was on fire, or was it a building that was illuminated? If this latter, then the mashal means that Abraham saw the world "illuminated" by the sun, moon and stars. Just as candles must have been lit by someone, so Abraham deduced that the universe must have a Prime Cause. Abraham ben Asher's explanation is reminiscent of Maimonides' account in Hilkhot 'Avodah Zarah:

Abraham saw the sun and the moon and the stars, the sun by day and the moon and stars by night. He said, "Surely someone must be setting them in motion - it would never be possible without someone in charge." 23

But Abraham ben Asher rejects this Maimonidean interpretation because it does not accurately reflect the meaning of birah doleket. Rather than a building "illuminated" by candles, he argues, it must mean a building "on fire." ${ }^{44} \mathrm{He}$ associates this with the ongoing destruction of the world by idolatry by citing Isaiah 50:11, in which those who do not fear

\footnotetext{
"כך אברהם ראה השמש והירח והכוכביי השמש ביום והירח והכוכבים בלילה אמר בודאי שיש מי שמניע אותם ואי אפשר לעולם בלא מנהיג" Abraham ben Asher, Or ha-Sekhel, f.81b. It is not possible to state with certainty that Abraham ben Asher made direct use Maimonides' account because, as indicated above, so many sources tell of Abraham's discovery of monotheism. His interpretation also resembles that of Pseudo-Rashi (f.81a): "[Abraham] saw the heavens and the earth. He saw the sun shining by day and the moon by night and the stars giving light. He said, 'Is it possible that there should be something as great as this without someone in charge?" However Abraham ben Asher, like Maimonides, refers to the motion of the celestial bodies while Pseudo-Rashi is interested in their existence.

${ }^{24}$ Yet Abraham ben Asher returns to the understanding of birah doleket as an "illuminated building" in a supplementary interpretation appended to the discourse (Abraham ben Asher, Or ha-Sekhel, f.81b). He refers to the account in Zohar Lekh Lekha (I:78a) in which Abraham imitates the divine act of creation by "gazing, testing and balancing" each part of the world except the Land of Israel. Abraham ben Asher suggests that the latter seemed "illuminated" to Abraham because it is a source of light for the rest of the earth. He thereby draws a parallel between the mashal and the Zoharic account - just as the wayfarer did not know who was responsible for illuminating the building, so the Zohar records that Abraham could not "test and balance" the Land of Israel to discover the force ruling over it. Therefore he said, "Might you say that this world has no one in charge?" because he did not perceive God until the revelation recorded at Genesis 12:1. It is of no consequence to Abraham ben Asher that this interpretation is founded on a definition of birah doleket that he initially rejected. The two expositions are not mutually exclusive, but add additional layers of meaning to the text. Abraham ben Asher thereby provides all the more proof that the words of the sages can be expounded so as to reveal harmonious interpretations. Cf. Bland, "Issues," 56; Pachter, "Homiletic," ix.
} 
God or heed his servant are called "kindlers of fire" and "lighters of firebrands." ${ }^{25}$ When Abraham recognised the danger of idolatry, he questioned not whether God exists, but rather why God did nothing to stop it. Abraham ben Asher explains:

[Abraham] said, Might you say that this world has no one in charge (manhig)? Even though it is said that the Holy One, blessed be he, does not supervise (mashgiah) the sublunar world because of his grand exaltedness and his greatness, it is not right that he should leave this world that he created without someone in charge to supervise (yashgiah) those who are lighting this fire, to frighten them and get rid of them, and to try to hire workers to put out the fire for their wages. This is to say that God should punish idolaters. He should command prominent people, reveal himself to them and tell them [both] to warn the children of the world not to worship idols and to make known the divinity of the Creator of the world. ${ }^{26}$

Abraham ben Asher places the question about God's providential care of the sublunar world into Abraham's mouth, though phrasing it carefully so as to suggest that it was not his own view. "Some say that God doesn't supervise the sublunar world," thought Abraham. This is the opinion described by Maimonides in Book 3 of the Guide of the Perplexed, that "God's providence ends at the sphere of the moon." Maimonides attributed this view to Aristotle as formulated by Alexander of Aphrodisias, ${ }^{27}$ but asserted that it was contrary to "the opinion of our Law" which defends free will and the principle of divine retribution. ${ }^{28}$

According to Abraham ben Asher, Abraham refuted this erroneous opinion by saying that God can and should appoint human leaders to take charge of the world and oppose idolatry. And when God subsequently revealed himself to Abraham saying, "I am the owner of the world," his immanence in the sublunar world was demonstrated beyond any doubt. God owns it and governs it, and therefore appointed Abraham to extinguish the fire of idolatry.

By turning a question about God's existence into a question about divine providence, Abraham ben Asher has exonerated his namesake from the most heinous philosophical error. Rather than doubting the existence of a Prime Cause, Abraham merely considered an incorrect opinion about divine providence. But Abraham ben Asher leaves no stone unturned and proceeds to defend the patriarch even from uncertainty in this regard, for

${ }_{25}$ They are commanded to "walk in the flame $(u r)$ of your fire." By citing this verse, Abraham ben Asher associates the idolatrous practices of Ur of the Chaldeans with the fire in the mashal under discussion.

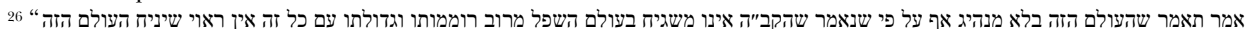

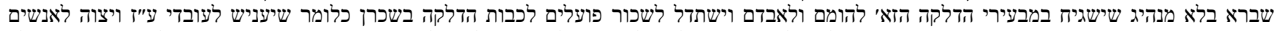
רשומים ויתגלה אליהם ויאמר להם להזהיר על בני העולם שלא יעבדו עבודה זרה ויפרסמות שלותו אלהות הבורא בעולם Sekhel, f.81b.

${ }^{27}$ Guide III:17. "The basis of [Aristotle's] opinion is as follows: Everything that, according to what he saw, subsisted continuously without any corruption or change of proceeding at all - as, for instance, the states of the spheres - or that observed a certain orderly course, only deviating from it in anomalous cases - as, for instance, natural things - was said by him to subsist through governance; I mean to say that divine providence accompanied it. On the other hand, all that, according to what he saw, does not subsist continuously or adhere to a certain order as for instance, the circumstances of individuals of every species of plants, animals, and man - are said by him to exist by chance and not through the governance of one who governs; he means thereby that they are not accompanied by divine providence, and he also holds that it is impossible that providence should accompany these circumstances." Moses Maimonides, The Guide of the Perplexed, trans. Shlomo Pines (Chicago: University of Chicago Press, 1963), 2:466.

${ }_{28}$ Maimonides also rejected this view in favour of what he styles here as his own opinion: that "in this lowly world - I mean that which is beneath the sphere of the moon - divine providence watches only over the individuals belonging to the human species." Guide III:17 (trans. Pines, 2:469-71). 
how could Abraham have misunderstood the nature of divine providence after God had saved him from the fiery furnace?

Abraham ben Asher turns to the question of Abraham's first prophetic apprehension of God and whether he attained it in the fiery furnace or later when he was commanded to leave his homeland. He points out that, in the mashal, the owner of the building "looked out" at Abraham and spoke to him. The verb used is "le-hatsits," which Abraham ben Asher defines as "to peep through a chink" (metsits min ha-hor). He therefore suggests that Abraham only had a very slight apprehension of God at this stage:

This means that, since [Abraham] was still not prepared for prophecy, "[The Lord] did not appear to him ..." (ve-khulei) as he appeared to him thereafter, but only as one peeping (metsits) through a chink ...29

This understanding of Abraham's prophecy might be compared to that of Nachmanides, who classed divine revelations to Abraham preceding his arrival in the land of Canaan (in Genesis 12:7) as of the same category as "dreams of the night" or revelations "by means of the holy spirit" rather than as prophetic visions proper. ${ }^{30}$ So too for Abraham ben Asher, Abraham neither attained a full prophetic apprehension of God in the fiery furnace nor even when he was commanded to leave his homeland, but at a later point in time. ${ }^{31}$ Though the patriarch pondered divine providence, therefore, he cannot be accused of uncertainty about the nature of a God who had already been prophetically revealed to him.

In the course of his exposition of this midrash, Abraham ben Asher leads the reader from the startling observation that the archetypal monotheist who had been saved by God from the fiery furnace appears to question the existence of a Prime Cause. Having

"פירוש לפי שעדין לא היה מוכן לנבואה לא נראה אליו וכו' כמו שנראה לו אחר כך אלא כמציץ מן החור" Abraham ben Asher, Or ha-Sekhel, f.81b. Abraham ben Asher's conclusion is similar to that of Isaac Arama who focused on Genesis Rabba 39:1 in his discussion of Lekh Lekha: "All the utterances mentioned and all the cases of the visions described in these stories [about the time] before he was called Abraham and before he was circumcised are all cases of the revelation of the Shekhinah and divine statement at a degree less than full prophecy. Instead, divine abundance went forth and was emanated upon [Abraham] at an ever increasing grade according to the [degree of] its fullness [that was added] to him, as we have said. Many utterances on a degree much lower than this had already occurred: 'and God came to Abimelekh [in a dream of the night]' (Gen. 20:3), '[and God came to Laban the Aramean in a dream of the night] and He said to him, "Keep yourself from speaking with Jacob" (Gen. 31:24), and several statements in the case of Hagar. But the greatest of them all is "and God spoke to the fish" (Jon. 2:11), as wrote the Rav, the teacher [Maimonides in the Guide for the Perplexed] in book 2, chapter 48." Isaac Arama, 'Akedat Yitshak, ed. Haim Pollack (Pressburg: Kittseer, 1849), vol. 1, f.119b. On Abraham's circumcision, cf. Genesis Rabba 48:2.

${ }^{30}$ Indeed, Abraham ben Asher may directly cite Nachmanides' commentary on Gen. 12:7 here (the verse reads "And the LORD appeared to Abram and said, 'To your seed I will give this land.' And he built an altar there to the LORD who had appeared to him."). "[The Lord] did not appear to him ... (ve-khulei)" appears to be a quotation, though no source is indicated. It may be Nachmanides' comment, which reads: "For until now the Lord had not appeared to him and he had not made himself known to him in an appearance (mar'eh) or in a vision (mahazeh). But 'Go from your land' was said to him in a dream of the night or by means of the holy spirit." (Moses Nachmanides, Perushei ha-Torah, ed. Charles Chavel (Jerusalem: Mossad ha-Rav Kook, 1959-60), 1:78). Compare the terms Nachmanides used to those of Maimonides in Guide II.45 (trans. Pines, 2:398-400) where "speaking through the Holy Spirit" and "a dream of the night" indicate the second degree of prophecy and therefore fall short of pure prophecy. This latter is referred to by Nachmanides by the terms mahazeh and mar'eh, though it is not clear whether any distinction between the two is intended here. By comparison, for Maimonides, the terms are synonymous, and may indicate either prophecy or an inferior degree of revelation (Guide II:43, 45; trans. Pines, 2:391-3, 396-404). See also Nachmanides' comment on Gen. 15:1.

${ }^{31}$ Abraham ben Asher, therefore, disagrees with Maimonides. In Guide II:41, Maimonides considers the mandate at Gen. 12:1 as the "fourth form" of prophecy in which the prophet does not mention that the revelation was through the agency of an angel or in a dream, but "simply says that God talked to him or told him: Act thus!" (trans. Pines, 2:386) Abraham ben Asher's views are closer to those of Nachmanides. 
captured the reader's interest, he skilfully interweaves details from the mashal with further aggadot about Abraham's early life and familiar philosophical ideas known from Maimonides' writings. Charting the course from problems to solutions, Abraham ben Asher guides the reader to a new interpretation of the midrash. Abraham did not question the existence of a Prime Cause, but pondered the errors of others regarding divine providence. He did not lapse into doubt after God was first revealed to him, but rather his prophetic apprehension gradually increased little by little.

Although the "doubts" that prompted this exposition were of Abraham ben Asher's own devising, and the astute reader knows that he always resolves them in the end, he applies the technique of asking and answering questions to Genesis Rabba with a clear purpose. The litanies of doubts awaken the reader's attention and curiosity, not primarily in whether the problems are soluble, but in how the expositor will go about the task. ${ }^{32} \mathrm{By}$ scrutinising the minutiae of the midrashic text, Abraham ben Asher calls attention to details that might otherwise be overlooked and thereby uncovers new layers of meaning latent within the sages' interpretations. By faithfully resolving each and every doubt and question, he creates and reinforces the impression that any uncertainties that may arise in the study of midrash will inevitably have satisfactory resolutions and that the rabbis' words can always be expounded so as to reveal harmonious and coherent meanings.

But nevertheless, for just a moment, Abraham ben Asher leads the reader to entertain the notion that Abraham doubted the existence of the God who had been revealed to him. A discourse framed around doubts and resolutions allowed for the expression of such an idea. It also prompts the reader to embark on the quest to disprove it, safe in the knowledge that Abraham ben Asher will resolve any doubts about Abraham doubting God.

\section{BIBLIOGRAPHY}

\section{Primary Sources}

Abraham ben Asher. Or ha-Sekhel. Venice: Giovanni Griffio, 1567.

Arama, Isaac. 'Akedat Yitshak. Edited by Haim Pollack. 6 vols. Pressburg: Kittseer, 1849.

Karo, Joseph. Shulhan Arukh. Edited by Zvi Preisler and Samuel Havlin. Jerusalem: Ketuvim, 1975.

Macho, Alejandro Díez, ed. Targum Palaestinense in Pentateuchum: Additur Targum Pseudojonatan ejusque Hispanica Versio. 5 vols. Madrid: Consejo Superior de Investigaciones Científicas, 1977-88.

Maimonides, Moses. The Guide of the Perplexed. Translated by Shlomo Pines. 2 vols. Chicago: University of Chicago Press, 1963.

- The Mishneh Torah. Edited by Moses Hyamson. 2 vols. New York: Feldheim, 1981.

Nachmanides, Moses. Perushei ha-Torah. Edited by Charles Chavel. 2 vols. Jerusalem: Mossad ha-Rav Kook, 1959-60.

\footnotetext{
32 The rhetorical purpose bears comparison with that of the petiha as described by Joseph Heinemann in "The Proem in the Aggadic Midrashim: A Form-Critical Study," in Scripta Hierosolymitana Volume XXII: Studies in Aggadah and Folk-Literature, ed. Joseph Heinemann and Dov Noy (Jerusalem: Magnes Press, 1971), 101-2.
} 
Shapiro, Elimelech. Divrei Elimelekh. Warsaw: Halter, 1890.

Midrash Rabbah. 2 vols. Vilna: Romm, 1878.

\section{Secondary Sources}

Adler, William. "Abraham and the Burning of the Temple of Idols: Jubilees' Traditions in Christian Chronography.” JQR 77 (1987): 95-117.

Allan, Nigel. "A Typographical Odyssey: The 1505 Constantinople Pentateuch.” Journal of the Royal Asiatic Society, Third Series, 1 (1991): 343-52.

Bakhos, Carol. The Family of Abraham: Jewish, Christian, and Muslim Interpretations. Cambridge, Mass.: Harvard University Press, 2014.

Ben-Naeh, Yaron. Jews in the Realm of the Sultans: Ottoman Jewish Society in the Seventeenth Century. Tübingen: Mohr Siebeck, 2008.

Benvenisti, David. Yehudei Saloniki ba-Dorot ha-Aharonim. Jerusalem: Kiryat Sefer, 1973.

Bland, Kalman. "Issues in Sixteenth-Century Jewish Exegesis." In The Bible in the Sixteenth Century, edited by David Steinmetz, 50-67. Durham, N.C.: Duke University Press, 1990.

Bregman, Marc. "Midrash Rabba and the Medieval Collector Mentality." In The Anthology in Jewish Literature, edited by David Stern, 196-208. Oxford: OUP, 2004.

Brock, Sebastian. "Abraham and the Ravens: A Syriac Counterpart to Jubilees 11-12 and its Implications.” JSJ 9 (1978): 135-52.

Davidson, Herbert. "The Study of Philosophy as a Religious Obligation." In Maimonides the Rationalist, 1-14. Oxford: Littman, 2011.

Ginzberg, Louis. The Legends of the Jews. 2nd ed. 2 vols. Philadelphia: Jewish Publication Society, 2003.

Gross, Abraham. "Spanish Jewry and Rashi's Commentary on the Pentateuch" [in Hebrew]. In Rashi Studies, edited by Zvi Steinfeld, 25-77. Ramat-Gan: Bar Ilan University Press, 1993.

Gutmann, Joseph. "Abraham in the Fire of the Chaldeans: A Jewish Legend in Jewish, Christian and Islamic Art." Frühmittelalterliche Studien 7 (1973): 242-52.

Hacker, Joseph. "The Intellectual Activity of the Jews of the Ottoman Empire During the Sixteenth and Seventeenth Centuries." In Jewish Thought in the Seventeenth Century, edited by Isadore Twersky and Bernard Septimus, 95-135. Cambridge, Mass.: Harvard University Press, 1987.

- "The Sephardi Sermon in the Sixteenth Century - Between Literature and Historical Source" [in Hebrew]. Pe 'amim 26 (1986): 108-27.

Hayward, Robert. "Inconsistencies and Contradictions in Targum Pseudo-Jonathan: The Case of Eliezer and Nimrod." In Targums and the Transmission of Scripture into Judaism and Christianity, 210-33. Leiden: Brill, 2009.

Heinemann, Joseph. "The Proem in the Aggadic Midrashim: A Form-Critical Study." In Scripta Hierosolymitana Volume XXII: Studies in Aggadah and Folk-Literature, edited by Joseph Heinemann and Dov Noy, 100-22. Jerusalem: Magnes Press, 1971.

Horovitz, Carmi. "Darshanim, Derashot and Derashah Literature in Medieval Spain." In vol. 1 of Moreshet Sepharad: The Sephardi Legacy, edited by Haim Beinart, 383-98. Jerusalem: Magnes Press, 1992. 
Kister, Menahem. "Observations on Aspects of Exegesis, Tradition, and Theology in Midrash, Pseudepigrapha, and other Jewish Writings." In Tracing the Threads: Studies in the Vitality of Jewish Pseudepigrapha, edited by John Reeves, 1-34. Atlanta: Scholars Press, 1994.

Kugel, James. Traditions of the Bible. Cambridge, Mass.: Harvard University Press, 1998.

Lawee, Eric. "Isaac Abarbanel: From Medieval to Renaissance Jewish Biblical Scholarship." In Hebrew Bible/Old Testament, vol. 2, From the Renaissance to the Enlightenment, edited by Magne Sæbø, 190-214. Göttingen: Vandenhoeck \& Ruprecht, 2008.

- "The Reception of Rashi's Commentary on the Torah in Spain: The Case of Adam's Mating with the Animals." JQR 97 (2007): 33-66.

Lerner, Myron. "The Works of Aggadic Midrash and the Esther Midrashim." In vol. 2 of The Literature of the Sages, edited by Shmuel Safrai, Zeev Safrai, Joshua Schwartz, and Peter Tomson, 133-229. Assen: Royal Van Gorcum and Fortress Press, 2006.

"The Editio Princeps of Midrash Hamesh Megillot: Studies in the Activities of Hebrew Printers in Constantinople and Pesaro" [in Hebrew]. In The A.M. Habermann Memorial Volume, edited by Zvi Malachi, 289-311. Lod: The Habermann Institute for Literary Research, 1983.

Mandel, Paul. "The Call of Abraham: A Midrash Revisited." Prooftexts 14 (1994): 267-84.

Molho, Michael. "The Talmud Torah School" [in Hebrew]. In Salonique: Ville-Mère en Israël, 60-66. Jerusalem and Tel Aviv: Centre de recherches sur le Judaïsme de Salonique, 1967.

Pachter, Mordechai. "Homiletic and Ethical Literature of Safed in the Sixteenth Century" [in Hebrew]. PhD diss., Hebrew University of Jerusalem, 1976.

Rozen, Minna. The Jewish Community of Jerusalem in the Seventeenth Century [in Hebrew]. Tel Aviv: Tel Aviv University and the Ministry of Defense, 1984.

Saperstein, Marc. "The Method of Doubts." In With Reverence for the Word, edited by Jane McAuliffe, Barry Walfish, and Joseph Goering, 133-56. Oxford: OUP, 2010.

- Jewish Preaching, 1200-1800: An Anthology. New Haven: Yale University Press, 1989.

Stern, David. Parables in Midrash: Narrative and Exegesis in Rabbinic Literature. Cambridge, Mass.: Harvard University Press, 1991.

Theodor, Judah. "The Commentary on Genesis Rabba" [in Hebrew]. In Festschrift zu Israel Lewy's siebzigstem Geburtstag, edited by Marcus Brann and Ismar Elbogen, 132-54 (Hebrew section). Breslau: Marcus, 1911.

Vermes, Geza. Scripture and Tradition in Judaism. 2nd ed. Leiden: Brill, 1961.

Weinberg, Joanna. "Abraham, Exile, and Midrashic Tradition." In Abraham, the Nations, and the Hagarites: Jewish, Christian, and Islamic Perspectives on Kinship with Abraham, edited by Martin Goodman, George van Kooten, and Jacques van Ruiten, 223-41. Leiden: Brill, 2010.

Williams, Benjamin. "The Ingathering of Midrash Rabba: A Moment of Creativity and Innovation." In Midrash Unbound: Transformations and Innovations, edited by Michael Fishbane and Joanna Weinberg, 347-70. Oxford: Littman, 2013.

- Commentary on Midrash in the Sixteenth Century: The Or ha-Sekhel of Abraham ben Asher. Oxford: OUP, forthcoming.

Yaari, Abraham. Hebrew Printing at Constantinople: Its History and Bibliography [in Hebrew]. Jerusalem: Magnes Press, 1967. 


\section{Acknowledgement}

Various extracts from pp.64-138 Ch.4 'Abraham ben Asher's Commentary - An Examination of Selected Texts' from "Commentary on Midrash Rabba in the Sixteenth Century: The Or ha-Sekhel of Abraham ben Asher" by Williams, Benjamin (2016). 